\title{
INICJATYWY POLITYCZNO-GOSPODARCZE STANÓW ZJEDNOCZONYCH ADRESOWANE DO KRAJÓW AFRYKI PÓŁNOCNEJ NA POCZĄTKU XXI WIEKU*
}

\author{
Rafał Wordliczek**
}

\author{
U.S. POLITICAL AND ECONOMIC INITIATIVES TOWARDS \\ NORTH AFRICA AT THE BEGINNING OF THE $21^{\text {ST }}$ CENTURY
}

ABSTRACT

\begin{abstract}
The Mediterranean Area is a very important region at the contemporary international relations scene. Since 2001, the United States have established closer relations with North African countries. There are two main goals of the American foreign policy towards Maghreb. The first one of these goals concerning cooperation is searching for the alternative way of supplying the United States by African gas and oil. Such countries as Algeria, Libya, and Nigeria are some of the biggest holders and exporters of these natural minerals. Nowadays, the U.S., the European countries and Russia are in rivalry for Liquefied Natural Gas (LNG) and oil contracts with the African partners. The winner of this competition will keep control of the whole market of minerals, and from the political, economic and strategic point of view will be stronger in the future. The second one is supporting by Maghreb countries the U.S. counter-terrorism military operation "Active Endeavour".
\end{abstract}

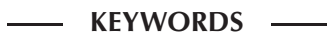

terrorism, Africa, the United States of America, economy

* Projekt został sfinansowany ze środków Narodowego Centrum Nauki przyznanych na podstawie decyzji numer DEC-2011/01/B/HS5/00930.

** Uniwersytet Jagielloński w Krakowie, Instytut Nauk Politycznych i Stosunków Międzynarodowych. 
W nowej epoce zagrożeń i szans naszym głównym celem powinno być rozszerzenie i umocnienie wspólnoty demokratycznych państw o gospodarce rynkowej. W czasie zimnej wojny staraliśmy się nie dopuścić do zagrożenia wolnych instytucji. Dziś zaś chcemy zwiększyć krąg narodów, które z tych instytucji korzystają, gdyż marzymy o dniu, gdy poglądy i energia każdego mieszkańca naszej planety znajdą pełny wyraz w świecie kwitnących, demokratycznych państw, które współpracując ze sobą, żyją w pokoju ${ }^{1}$.

William Clinton, 42. prezydent Stanów Zjednoczonych

Stany Zjednoczone są jednym z dominujących graczy współczesnych stosunków międzynarodowych. Polityka zagraniczna USA, mocarstwa światowego w systemie unipolarnym prowadzona wobec wielu aktorów międzynarodowej sceny politycznej, jest przedmiotem zainteresowania i analizy wielu badaczy przedmiotu. Bez względu na zmiany polityczne w USA wybierani prezydenci posiadają zdolność prowadzenia aktywnej polityki wobec różnych rejonów świata ${ }^{2}$. Obszary międzynarodowego zaangażowania Stanów Zjednoczonych pozostają niezmienne od wielu lat. Dotyczą one głównie działań na rzecz bezpieczeństwa globalnego, pozycji hegemona USA na świecie, promocji praw człowieka, demokracji i wolności oraz zapewnienia bezpieczeństwa

1 Prezydent Bill Clinton, Confronting the Challenges of a Broader World, przemówienie na forum Zgromadzenia Ogólnego ONZ w Nowym Jorku 27 września 1993 r., [za:] H. Kissinger, Dyplomacja, Warszawa 2002, s. 885 .

${ }^{2} \mathrm{~W}$ międzynarodowym środowisku politologów i analityków od kilkunastu lat trwa debata na temat rzeczywistej roli USA w stosunkach międzynarodowych po zakończeniu zimnej wojny. Szerzej o pozycji USA w systemie międzynarodowym po 1989 roku piszą m.in. Strategy for Empire. US Regional Security Policy in the Post-Cold War Era, red. B. Loveman, Lanham 2004; America's Startegic Choices, red. M.E. Brown, O.R. Cote, Jr., S.M. Lynn-Jones, S.E. Miller, Cambridge 1997, US Allies in a Changing World, red. B. Rubin, T.A. Keaney, London 2001; M.J. Rochester, US Foreign Policy in the Twenty - First Century, Philadelphia 2008; M. Cox, US Foreign Policy after the Cold War. Superpower without a Mission?, London 1995; J.M. Lindsay, US Foreign Policy after the Cold War, Pittsburgh 1997; F. Fukuyama, Ameryka na rozdrożu. Demokracja, władza i dziedzictwo konserwatyzmu, Poznań 2006; Z. Brzeziński, B. Scowcroft, Ameryka i Świat. Rozmowy o globalnym przebudzeniu politycznym, Łódź 2010; S.W. Hook, US Foreign Policy Today, Washington D.C. 2011. Z prac polskich autorów należy wymienić przede wszystkim: Polityka zagraniczna USA po zimnej wojnie, red. J. Zając, Toruń 2005; R. Fiedler, Od przywództwa do hegemonii. Stany Zjednoczone wobec bliskowschodniego obszaru niestabilnosci w latach 1991-2009, Poznań 2010; W. Szymborski, Doktryna Busha, Bydgoszcz 2004; W. Malendowski, Nowy ład międzynarodowy in statu nascendi, Poznań 1993. 
energetycznego. Charakterystyczną cechą globalnej polityki USA jest obecność w regionach o niskim stopniu zainteresowania. Głównym celem artykułu jest zdefiniowanie priorytetów amerykańskiej polityki zagranicznej wobec takich obszarów. Przykładem rejonu o niskim stopniu zainteresowania jest, a raczej do niedawna był, basen Morza Śródziemnego, a ściślej rzecz biorąc, kraje Afryki Północnej ${ }^{3}$.

Od kilkunastu lat można zauważyć ewolucję polityki USA wobec krajów Maghrebu i zwiększone zainteresowanie ze strony hegemona ${ }^{4}$. W czasie zimnej wojny z powodu zaangażowania USA w innych regionach świata zmniejszyła się amerykańska aktywność polityczna wobec północnej Afryki. Z powodów strategicznych i prestiżowych od początku XXI wieku państwa północnoafrykańskie zajmują coraz ważniejsze miejsce w polityce Waszyngtonu. Ze względu na geostrategiczne położenie i rolę $\mathrm{w}$ walce $\mathrm{z}$ międzynarodowym terroryzmem oraz na zasoby surowców energetycznych, którymi dysponują, Amerykanie aktywizują działania wobec krajów Maghrebu. Północnoafrykańskie złoża gazu ziemnego i ropy naftowej mogą stanowić znaczne wsparcie surowcowe dla gospodarki amerykańskiej. W przyszłości mogłyby stać się wręcz zapleczem surowcowym dla USA. Z tego powodu od ponad 10 lat obserwujemy coraz ostrzejszą rywalizację o wpływy w tych regionach pomiędzy Waszyngtonem a Chinami i Rosją. Jednym z problemów hamujących ofensywę polityczną Waszyngtonu są antydemokratyczne rządy w wielu krajach afrykańskich i presja międzynarodowych organizacji walczących o prawa człowieka wywierana na decydentów amerykańskich. Celem presji jest uzależnienie aktywności polityki gospodarczej i bezpieczeństwa USA w tym rejonie z procesem demokratyzacji. Czynnik ten nie wpływa korzystnie na współpracę państw Maghrebu ze Stanami Zjednoczonymi, które muszą opierać swoje działania na hasłach demokratyzacji i wolności. Natomiast powyższy czynnik nie determinuje działań rządów Rosji czy Chin dotyczących gospodarczej i politycznej współpracy z dyktatorami krajów Afryki Północnej. Zagrożenia wynikające z rywalizacji polityczno-gospodarczej pomiędzy tymi

${ }^{3}$ Pomimo amerykańskich inicjatyw politycznych i gospodarczych adresowanych zarówno do krajów Maghrebu, jak i Bliskiego Wschodu należy zaznaczyć, iż wielu badaczy przedmiotu rozgranicza te obszary z punktu widzenia priorytetów amerykańskiej polityki zagranicznej USA. Różnice między ww. terenami widoczne są również w działaniach Unii Europejskiej. J. Zając, Role Unii Europejskiej w regionie Afryki Północnej i Bliskiego Wschodu, Warszawa 2010; eadem, Polityka Unii Europejskiej w regionie śródziemnomorskim, Torun 2002.

4 United States Interests and Policy in Africa: Transition to New Era, red. K.P. Magyar, New York 2000, s. 17. 
państwami skłaniają USA do prowadzenia coraz aktywniejszej polityki wobec regionów o niskim stopniu zainteresowania.

Z geopolitycznego punktu widzenia interesów USA i stopnia zaangażowania należy wymienić trzy zasadnicze grupy regionów świata:

- regiony szczególnej troski: Europa Zachodnia, Bliski Wschód, Pacyfik,

- regiony czujnej obserwacji: Ameryka Łacińska, Europa Środkowo-Wschodnia,

- obszary wnikliwego nadzoru: Rosja, Chiny5.

Znamienne, iż w żadnej z grup nie zostały ujęte kraje afrykańskie, włącznie z krajami Afryki Północnej ${ }^{6}$. Wyjątek stanowi Egipt, który zaliczany jest do obszaru Bliskiego Wschodu. Afryka to jeden z przykładów obszarów o małym zainteresowaniu z punktu widzenia interesów USA7 . Analiza polityki zagranicznej USA po 1945 roku pokazuje jej ewolucję poprzez systematyczne przechodzenie na pozycje defensywne wobec krajów Maghrebu na rzecz większego zaangażowania w Azji czy Europie. Potwierdzeniem marginalnego traktowania państw Afryki Północnej przez kolejne administracje waszyngtońskie podczas zimnej wojny jest włączenie tych terenów dopiero w 1952 roku do działania w ramach europejskiego dowództwa USEUCOM. Z powodów geopolitycznych, historycznych (dawne kolonie francuskie) i kulturowych odpowiedzialność za Algierię, Maroko, Tunezję oraz Libię przejęło europejskie dowództwo USCOM. Stany Zjednoczone dostrzegły potrzebę objęcia swym działaniem ten region dopiero w latach dziewięćdziesiątych XX wieku, podczas gdy już w 1946 roku Amerykanie ustanowili siedem US Command dla siedmiu regionów świata: Far East Command, Pacific Command, Atlantic Fleet, European Command, Alaskan Command, Caribbean Command oraz Northeast Command ${ }^{8}$. Sytuacja uległa radykalnej zmianie wobec pojawienia się współczesnych zagrożeń w stosunkach międzynarodowych, tj. międzynarodowego terroryzmu czy proliferacji

5 US Allies in a Changing World, red. B. Rubin, T.A. Keaney, London 2001, s. 40.

6 Przykładowo, w dokumencie National Security Strategy, przedstawionym przez prezydenta Billa Clintona Kongresowi USA w lutym 1996 roku, we fragmencie poświęconym problemom Afryki mowa jest jedynie o krajach Afryki Subsaharyjskiej, brak wzmianki o północnej części kontynentu. Bezpieczeństwo narodowe i międzynarodowe u schyłku XX wieku, red. E. Haliżak Edward, B.D. Bobrow, R. Zięba, Warszawa 1997, s. 211.

7 P. Pacuła, Główne kierunki polityki zagranicznej Stanów Zjednoczonych. Cele strategiczne, narzędzia ich realizacji, „Raport Biura Bezpieczeństwa Narodowego” 2007, nr 5-6, 2007, s. $32-33$.

8 Strategy for Empire. US Regional Security Policy in the Post-Cold War Era, red. B. Loveman, Oxford 2004, s. 136. 
broni masowego rażenia. Zasadniczymi celami polityki zagranicznej Stanów Zjednoczonych okazała się walka z Irakiem, następnie po 11 września 2001 roku zaangażowanie militarne $\mathrm{w}$ Afganistanie, walka $\mathrm{z}$ międzynarodowym terroryzmem, stosunki $z$ Iranem. Od tego momentu region śródziemnomorski w polityce zagranicznej USA zajmuje bardzo ważne miejsce i stanowi kluczowy element $\mathrm{w}$ realizacji priorytetów tej polityki ${ }^{9}$.

Stany Zjednoczone od początku obecności militarnej i politycznej w basenie Morza Śródziemnego, od czasów II wojny światowej, przez okres ponad pięćdziesiąt lat podejmowały różne działania wobec tego regionu. Przykładem jest obecność VI floty USA na wodach Morza Śródziemnego i ustanowienie jej siedziby we włoskim porcie Gaeta. Jednak działania te nie dotyczyły całego obszaru śródziemnomorskiego. Priorytetem dla Waszyngtonu, z wielu powodów, pozostawał konflikt bliskowschodni i pokojowe próby jego rozwiązania. Na marginesie głównego nurtu polityki śródziemnomorskiej USA znajdowały się kraje Afryki Północnej, poza Egiptem, który choćby z racji położenia geograficznego i zaangażowania $w$ konflikt $z$ Izraelem był ważnym elementem amerykańskiej polityki wobec Bliskiego Wschodu. W okresie zimnej wojny rejon Morza Śródziemnego był terenem bipolarnej rywalizacji militarno-politycznej pomiędzy Stanami Zjednoczonymi a Związkiem Radzieckim ${ }^{10}$. Pomimo tego faktu jednak aż do przełomu XX i XXI wieku Maroko, Algieria, Tunezja i Libia były traktowane przez kolejne administracje waszyngtońskie jako obszar o niskim stopniu zainteresowania/zaangażowania. Po upadku żelaznej kurtyny w wyniku zmiany układu sił na świecie, wytworzenia się układu unipolarnego $\mathrm{z}$ dominującą pozycją USA oraz na skutek pojawienia się nowych zagrożeń dla ładu międzynarodowego (terroryzm międzynarodowy, przeciwdziałanie terrorystom islamskim, utworzenie w ramach walki z Al-Kaidą African Center for the Study and Research on Terrorism z siedzibą w Algierii ${ }^{11}$ oraz nowych wyzwań o charakterze ekonomicznym (poszukiwanie nowych źródeł dostaw surowców naturalnych, ambitny projekt utworzenia z inicjatywy George'a W. Busha Middle East Free Trade Area) należy zauważyć ewolucję polityki USA wobec tych krajów, polegającą na zwiększonym stopniu intensywności kontaktów bilateralnych.

9 US Strategy in Africa. AFRICOM, Terrorism and Security Challenges, red. D.J. Francis, London-New York 2011, s. 38.

10 Szerzej: R. Vukadinović, The Mediterranean between War and Peace, Belgrad-Zagrzeb 1987.

11 US Strategy in Africa..., op.cit., s. 142. 
Jednym z przykładów intensyfikacji kontaktów dwustronnych między USA a krajem północnoafrykańskim w ostatnich latach jest Algieria, której znaczenie jako jednego $\mathrm{z}$ większych światowych eksporterów gazu ziemnego jest nie do przecenienia $^{12}$. Z kolei pod kątem walki z terrorystami islamskimi po 2001 roku Algier okazał się lojalnym i ważnym partnerem dla Waszyngtonu. O aktywności i niebezpieczeństwie wynikającymi z działań Al-Kaidy w tym kraju świadczy szereg akcji wymierzonych zarówno w ludność cywilną, jak i Amerykanów działających w Algierii. Do jednego z takich ataków doszło w 2006 roku, kiedy to islamiści uderzyli na konwój pracowników amerykańsko-algierskiej firmy Brown \& Root-Condor. W wyniku ataku na hotel w mieście Bouchaaoui zginął jeden Algierczyk, a dziewięć osób, w tym czterech Brytyjczyków i jeden Amerykanin, zostało rannych ${ }^{13}$.

Fundamentalną kwestią polityki zagranicznej USA prowadzonej wobec krajów Maghrebu na przełomie XX i XXI wieku jest problem bezpieczeństwa międzynarodowego, na który w głównej mierze składa się walka z międzynarodowym terroryzmem. Na marginesie walki z terroryzmem pozostają działania mające na celu wspieranie przemian politycznych, jakie zostały zapoczątkowane w 2010 roku. Kraje Maghrebu odgrywają w ogłoszonej przez prezydenta Busha w 2001 roku polityce War on Terror bardzo ważną rolę. Należy wymienić dwie kluczowe role przewidziane przez prezydenta G.W. Busha do odegrania przez kraje Magrebu w walce przeciw terroryzmowi. Sojusznicy z Afryki Północnej mają stanowić zaplecze do działań wojennych w Iraku i Afganistanie (operacja Active Endeavour) oraz wspierać utworzenie kolejnego frontu w ramach Global

12 Zbliżenie amerykańsko-algierskie dotyczy dwóch obszarów współdziałania: wspólna walka przeciw terroryzmowi i kwestie gospodarcze. Współpraca gospodracza pomiędzy USA a Algierią dotyczy przede wszystkim inwestycji amerykańskich w algierski sektor energetyczny i przemysł wojskowy. Kooperacja została zintensyfikowana w wyniku spotkania prezydenta Algierii Aldelaziza Bouteflika z prezydentem George’em W. Bushem, które miało miejsce w Wasztngtonie w lipcu 2003 roku. Wymiernymi wynikami spotkania było ustanowienie spółki joint venture Brown \& Root Condor, której udziałowcami zostali amerykańska firma Halliburton oraz algierskie przedsiębiorstwo państwowe z branży energetycznej Sonatrach. Brown \& Root - Condor otrzymała lukratywny kontrakt na budowę i wyposażenie powietrznych baz wojskowych w algierskich miastach Tamanrasset oraz Bou Saada. W walce przeciwko terrorystom Amerykanie oczekiwali od Algierii udostępnienia terenów pod bazy wojskowe oraz wyrażenia zgody co do ustanowienia ewentualnej siedziby AFRICOM. C.S. Smith, US Training African Forces to Uproot Terrorists, „New York Times”, 11.05.2004, www.nyt.com, odczyt z dn. 23.04.2012.

13 C.S. Smith, Qaeda - Linked Group Claims Algerian Attack, „New York Times”, 13.12.2006, www. nyt.com, odczyt z dn. 29. 09. 2012. 
War on Terror (GWOT) ${ }^{14}$, który swym zasięgiem obejmuje tereny od Somalii przez kraje Maghrebu aż do zachodnich wybrzeży Afryki.

Oficjalnie afrykański front GWOT powstał w styczniu 2004 roku. Część analityków amerykańskich źródło utworzenia frontu w Afryce wiąże z zasobami surowców energetycznych, które znajdują się w Afryce Zachodniej i Północnej. W nieodległej perspektywie czasowej złoża afrykańskie dla gospodarki amerykańskiej staną się potencjalną alternatywą dla dostaw ropy i gazu z niestabilnego regionu Zatoki Perskiej. Początek GWOT w Afryce oraz utorzenie AFRICOM to nic innego jak przygotowanie do przejęcia przez USA kontroli militarnej, a dzięki afrykańskim sojusznikom również politycznej nad terenami bogatymi w złoża strategicznych surowców energetycznych, ropy naftowej i gazu ziemnego ${ }^{15}$. W maju 2001 roku prezydent Bush podjął decyzję o ogłoszeniu National Energy Policy Development (NEPD). Pod przewodnictwem wiceprezydenta Dicka Cheneya specjalny zespół ekspertów skupionych w NEPD opracował raport dotyczący perspektyw współpracy amerykańsko-afrykańskiej w dziedzinie energetyki. Raport Cheneya wskazywał, iż wobec zwiększonego zapotrzebowania na surowce energetyczne przez USA kraje Afryki Północnej i Zachodniej są postrzegane w najbliższej przyszłości jako główne źródło napływu surowców dla gospodarki amerykańskiej. Według prognoz do 2020 roku zapotrzebowanie w USA na ropę naftową wzrośnie o 40\%, a na gaz ziemny o 32\% ${ }^{16}$. W 2006 roku prezydent Bush określił, iż wykorzystanie zasobów złóż energetycznych tej części Afryki na potrzeby gospodarki amerykańskiej w przyszłości stanowi our strategic national interest ${ }^{17}$.

Kolejnym ważnym powodem zwiększonego zainteresowania tym regionem przez USA jest przyczyna geostrategiczno-propagandowa. W momencie ogłoszenia przez prezydenta Busha wojny z islamskim terroryzmem kraje arabskie były potrzebne, aby uwiarygodnić amerykańską politykę oraz udowodnić,

14 Okoliczności utworzenia frontu GWOT w Afryce i kontrowersje związane z tym faktem szerzej zostały przedstawione w pracy: R. Wordliczek, North Africa in the U.S Foreign Policy at the End of the 20th and the Beginning of the 21st Century: Challenges and Expectations, „Ad American” 2012, vol. 13.

15 D. Volman, The Bush Administartion \& African Oil: The Security Implications of US Energy Policy, „Review of African Political Economy” 2003, nr 30 (98), s. 579.

16 US Department of Energy, Energy Information Administration, US Total Crude Oil and Products Import, 25.03.2008, http://tonto.eia.doe.gov/dnav/pet/pet_move_impcus_a2_nus_ep00_im0_ mbbl_m.htm, odczyt z dn. 23.05.2012.

17 Obecnie znaczenie strategiczne krajów Afryki Północnej pod kątem energetycznym dla gospodarki amerykańskiej zmalało z powodu rozpoczęcia wydobycia gazu łupkowego na szeroką skalę na terenie Stanów Zjednoczonych. 
iż działania Amerykanów mają charakter multilateralny. Obecność takich krajów arabskich jak Algieria czy Maroko w koalicji antyterrorystycznej miała podwójne znaczenie propagandowe dla Waszyngtonu. W ten sposób prezydent Bush zyskiwał koronny argument w przekonaniu innych krajów do przystąpienia do walki z terrorystami. Od momentu ogłoszenia GWTO wojna przeciw Al-Kaidzie to nie jest samotna walka USA, ponieważ poparcia udzielają inne państwa, np. tacy europejscy sojusznicy, jak: Polska, Wielka Brytania, Włochy, a co najważniejsze państwa islamskie. Powstanie takiej możliwości było bardzo korzystne dla Waszyngtonu, tym bardziej że niektórzy europejscy sojusznicy odmówili pomocy Amerykanom ${ }^{18}$. Ze względów wizerunkowych idealnie do tej roli nadawały się kraje Maghrebu; ta część Afryki z powodów religijnych, etnicznych and kulturowych jest w większym stopniu zaliczana do krajów basenu Morza Śródziemnego czy świata arabskiego niż Afryki. Innymi słowy, Amerykanie mogli pokazać opinii światowej, że wojnę z terroryzmem popierają państwa północnoafrykańskie, traktowane nie jako przedstawiciele kontynentu afrykańskiego, ale jako reprezentanci świata muzułmańskiego ${ }^{19}$.

Jak olbrzymią rolę odgrywają w amerykańskiej polityce war on terror ${ }^{20}$ kraje Maghrebu, świadczy fakt zainicjowania wielu programów i operacji polityczno-militarnych. Uczestnikami tych inicjatyw są zarówno państwa Afryki subsaharyjskiej, jak i Maroko, Algieria, Tunezja, Egipt i Libia. Już w 2002 roku Amerykanie powołali do życia Pan-Sahel Counter-Terrorism Initiative (PSCTI) ${ }^{21}$, przekształcona w końcu 2004 roku w Trans-Saharan Counter-Terrorism

18 Przykładem jest Francja i antyamerykańska postawa prezydenta Chiracqa zaprezentowana bezpośrednio po wydarzeniach z 11 września 2001 r. Już w latach dziewięćdziesiątych politycy francuscy wyrażali się krytycznie o dominacji USA w systemie światowym. Słowami ówczesnego ministra spraw zagranicznych Francji Huberta Vedrine Paryż stwierdzał: „Francja nigdy nie zaakceptuje unipolarnego systemu na świecie lub unilateralizmu jednego supermocarstwa”. Wywiad z ministrem spraw zagranicznych Francji Hubertem Vedrine, „Liberation” 24.11.1998, [za:] Strategy for Empire. US Regional Security Policy in the Post-Cold War Era, red. B. Loveman, Oxford 2004, s. 53.

19 R.G. Catoire, op.cit., s. 138.

20 Kluczową dla działań zbrojnych w Afganistanie (Enduring Freedom) i Iraku (Iraqi Freedom) jest rozpoczęta w październiku 2001 roku i obejmująca swym zasięgiem Morze Śródziemne operacja antyterrorystyczna Active Endeavour. Od samego początku misji Amerykanów lojalnie wspierają Algieria i Maroko. A. Moens, The Foreign Policy of George W. Bush. Values, Strategy, and Loyalty, Burlington 2004, s. 133.

21 Początki programu Pan-Sahel Terrorism Initiative były bardzo skromne. W 2002 roku tworzyły ją jedynie cztery kraje: Czad, Mali, Niger oraz Mauretania, a budżet wynosił jedynie niecałe $7 \mathrm{mln}$ USD. PSTI działała w ramach większej struktury The Special Operations Command Europe (SOEUR). Amerykanie szkolili żołnierzy w zakresie walki z terrorystami oraz personel w zakresie obsługi 
Partnership (TSCTP). W 2005 roku akces do TSCTP zgłosiło dziewięć państw afrykańskich; z Afryki Subsaharyjskiej: Mali, Czad, Niger, Nigeria i Senegal oraz z Afryki Północnej: Mauretania, Tunezja, Algieria oraz Maroko. Celem działania TSCTP jest szkolenie i przygotowanie przez US Army Special Forces żołnierzy krajów afrykańskich do walki z międzynarodowym terroryzmem. Na potrzeby tej struktury w 2007 roku w budżecie amerykańskim zarezerwowano środki w wysokości $82 \mathrm{mln}$ USD, a od 2011 roku zaplanowano wydatki na poziomie $100 \mathrm{mln}$ USD rocznie ${ }^{22}$. Nowa forma współpracy zainaugurowała działanie w czerwcu 2005 roku wspólną akcją szkoleniową o pseudonimie Flintlock 05 przeprowadzoną przez Join Combined Exchange Training (JCET). 1000 Amerykanów przybyło do krajów zachodniej i północnej Afryki, aby przeszkolić 3000 Afrykańczyków - członków lokalnych służb. Dwa lata później ćwiczenia powtórzono pod kryptonimem Flintlock 07.W drugim przypadku Amerykanów wspierali w szkoleniach żołnierze brytyjscy, Holendrzy oraz - co było zarówno cenne, jak i symboliczne oraz pragmatyczne - Francuzi. Celem ćwiczeń było „to help participating nations to plan and execute command, control and Communications system in suport of future combined humanitarian, pegacekeeping and disaster relief operations. [...] The training is to ensure all nations continue developing their partnerships. [...] To halt the flow of illicit weapons, foods and human trafficking in the region; and prevent terrorists from establishing sanctuary in remote areas" ${ }^{23}$. Pentagon, zachęcony sukcesami współpracy, pod koniec 2007 roku wprowadził pewne modyfikacje do programu. Zmieniono nazwę na Trans-Sahara Counter-Terrorism Program (TSCTP), a w konsekwencji kraje afrykańskie uczestniczące w TSCTP uzyskały zwiększoną pomoc finansową

i ochrony baz lotniczych, opieki medycznej, a także umiejętności posługiwania się systemem GPS. W lipcu 2003 roku do porozumienia przystąpiła Algieria. Pierwszy sprawdzian umiejętności żołnierzy z tych krajów miał miejsce na początku 2004 roku. Terroryści zaatakowali konwój humanitarny na północy Mali zabezpieczany przez algierskie siły zbrojne. W wyniku walki oddziały terrorystów rozbito, a uciekinierzy, którzy znaleźli się w Czadzie, zostali pojmani i przekazani Amerykanom na podstawie porozumienia PSTI.S. Ellis, Briefing: The Pan-Sahel Initiative, „African Affairs” 2004, nr 103 (412), s. 460.

${ }^{22}$ Ibidem, s. 464.

23 „Pomoc krajom uczestniczącym w programie w planowaniu i wykonywaniu zadań, w kontroli system łączności, który może być wykorzystany przy wspólnych akcjach o charakterze humanitarnym, pokojowym czy w zwalczaniu skutków klęsk żywiołowych. Ćwiczenia mają wzmocnić współpracę pomiędzy uczestnikami programu, zwalczać niekontrolowany handel bronią, ograniczyć proces nielegalnej imigracji oraz powstrzymać terrorystów przed aktywną działalnością w tym regionie" [tłum. własne]. EUCOM, Exercise Flintlock 05 Under Way in Africa, 9 June 2005, www. eucom.mil/ English/FullStory.asp?art=565, odczyt z dn. 20.12.2012. 
oraz logistyczną od Departamentu Stanu, Departamentu Skarbu i US Agency for International Development (USAID). Dodatkowo zostały objęte projektem The AntiTerrorism Assistance (ATA) oraz The Terrorist Interdiction Program (TIP) ${ }^{24}$. W 2006 roku Amerykanie zdecydowali się na ogłoszenie kolejnego programu militarnego, którego nolens volens beneficjentami stali się dyktatorzy afrykańscy. The Foreign Military Sale (FMS) skierowany był do lojalnych afrykańskich sojuszników Waszyngtonu w wojnie z terroryzmem. Program miał na celu sprzedaż broni amerykańskiej krajom afrykańskim, które miały użyć jej do walki z terrorystami. Prezydent Algierii Bouteflika wykorzystał sprzęt również do rozprawy z opozycją, przy bierności Amerykanów, dla których priorytetem było algierskie wsparcie dla wojny z międzynarodowym terroryzmem. Program decyzją rządu USA został wsparty systemem preferencyjnych pożyczek, a nawet grantów na zakup sprzętu przez Afrykańczyków. Widoczna jest różnica w finansowaniu zakupów, która wskazuje na strategiczne znaczenie północnej części Afryki w operacji przeciw terroryzmowi. W 2006 roku dla krajów Afryki subsaharyjskiej przeznaczono 14 mln USD, natomiast tylko dla dwóch krajów Maghrebu - Maroka i Tunezji - wyasygnowano sumę w wysokości $21 \mathrm{mln}$ USD. W ramach programu Direct Commercial Sales (DCS), który miał na celu sprzedaż uzbrojenia i wyposażenia sił policyjnych w krajach afrykańskich, dysproporcje były jeszcze większe. W 2008 roku Algieria otrzymała aż $175 \mathrm{mln}$ USA, natomiast Maroko $19 \mathrm{mln}$ USD, a dla porównania Botswana tylko $2 \mathrm{mln}$ USD, Kenia $3 \mathrm{mln}$ USD, Nigeria $17 \mathrm{mln}$ USD. Stosunkowo duże fundusze, w wysokości $61 \mathrm{mln}$ USD, przypadły Republice Południowej Afryki ${ }^{25}$.

Ważnym krokiem, dostrzegającym rolę kontynentu afrykańskiego w systemie zbiorowego bezpieczeństwa współcześnie, było utworzenie 6 lutego 2007 roku $^{26}$ decyzją prezydenta Busha afrykańskiego dowództwa USA AFRICOM i wydzielenie w jego ramach pięciu regionalnych sił szybkiego reagowania, w tym NASBRIG (North African Standby Brigade), obejmującego zasięgiem swego działania Afrykę Północną ${ }^{27}$. Ważną i bardzo delikatną kwestią było podjęcie decyzji w sprawie ustanowienia siedziby AFRICOM. Amerykanie przeprowadzili wiele konsultacji z rządami różnych krajów afrykańskich, które potencjalnie mogły

\footnotetext{
24 US Strategy in Africa..., op.cit., s. 71.

25 Ibidem, s. 74.

26 Pełną gotowość operacyjną AFRICOM uzyskało 1 października 2008 roku.

27 G.W. Bush, Transcript of President Bush's comments on US Africa Command (AFRICOM), Council of Foreign Relations, www.cfr.org/publication/13255, odczyt z dn. 13.02.2012.
} 
zostać wybrane na siedzibę AFRICOM. Z powodu silnych tendencji antyamerykańskich obecnych wśród społeczeństw afrykańskich, wynikających w dużej mierze z obaw przed rekolonizacją Afryki tym razem przez USA, władze m.in. Maroka, Libii, Egiptu, Kenii czy Nigerii zrezygnowały z dalszych rozmów w sprawie ustanowienia siedziby AFRICOM. Jedynie rządy Algierii i Liberii wyraziły gotowość wzięcia politycznej odpowiedzialności z tytułu ewentualnego przyjęcia na siebie roli gospodarza AFRICOM. W czerwcu 2007 roku Ryan Henry, jeden z wysokich urzędników Departament Obrony, doceniając postawę obu partnerów, zwłaszcza w obliczu powstałych nowych problemów, ogłosił decyzję, iż USA nie zamierzają w najbliższym czasie ustanawiać siedziby dowództwa AFRICOM w żadnym afrykańskim państwie. Problemami, które zaważyły na podjęciu takiej decyzji, były kwestie związane z finansowaniem siedziby dowództwa AFRICOM, oraz wzrost nastrojów antyamerykańskich, przede wszystkim w Algierii. 1 sierpnia 2007 roku podsekretarz stanu ds. obrony Theresa Whelan podjęła decyzję, iż siedzibą AFRICOM będzie Stuttgart. Na potrzeby stworzenia i funkcjonowania siedziby AFRICOM tylko w 2009 roku Waszyngton wyasygnował sumę $398 \mathrm{mln}$ $\mathrm{USD}^{28}$.

Innym aspektem większego zaangażowania administracji prezydenta Busha w Afryce Północnej - obok działań o charakterze polityczno-militarnym - jest współpraca gospodarcza i związana z nią aktywność Chin na kontynencie afrykańskim ${ }^{29}$.Zwłaszcza na tym polu dostrzec można ewolucję polityki zagranicznej administracji G.W. Busha i prezydenta B. Obamy. Czy ekspansja ekonomiczna Chin w Afryce, także w obszarze Maghrebu, ma kluczowe znaczenie dla stosunków z USA i przyszłości AFRICOM? Początki chińskiej ekspansji gospodarczej na kontynencie afrykańskim sięgają listopada 2006 roku, kiedy ChRL zorganizowała w Pekinie szczyt Chiny-Afryka na temat współpracy gospodarczej (FOCAC Forum on China - Africa Cooperation $)^{30}$. Pekin przewiduje w swym planie wiele obszarów współpracy gospodarczej. Kluczowe są inwestycje w infrastrukturalny rozwój państw Czarnego Lądu. Podczas gdy działania Zachodu w czasie arabskiej wiosny skupiały się na rozwiązaniach politycznych (rozwiązanie konfliktu, presja

28 D. Tate, US Officials Brief Congress on New Military Command for Africa, Voice of America, August 1, 2007, www.voanew.com, odczyt z dn. 19.06.2012.

${ }^{29}$ O pozycji Chin we współczesnym świecie, również na kontynencie afrykańskim, więcej zob. w: E. Haliżak, Polityka i strategia Chin w kształtowaniu międzynarodowego bezpieczeństwa, Warszawa 2008 oraz idem, Zmiana układu sił USA - Chiny a transformacja porządku międzynarodowego, Warszawa 2005.

30 US Strategy in Africa..., s. 166. 
zachodniej opinii publicznej w zakresie ochrony praw człowieka), Chiny prowadziły działania ofensywne w zakresie gospodarki. Rząd chiński wspiera politycznie i finansowo prywatnych inwestorów i zachęca do inwestowania w krajach afrykańskich. W zamian np. pułkownik Kadafi zezwalał na eksploatację libijskich zasobów energetycznych przez koncerny chińskie praktycznie na nieograniczoną skalę. Owocna współpraca dla dwóch stron spowodowała zajęcie przez Chiny wrogiej postawy wobec wydarzeń w Libii w 2011 roku i możliwości obalenia dyktatury Kadafiego. 17 marca 2011 roku na forum Rady Bezpieczeństwa ONZ Chiny - obok Rosji, Brazylii, Niemiec oraz Indii - wstrzymały się od poparcia akcji lotniczej NATO przeciw dyktatorowi libijskiemu i nie udzieliły autoryzacji tej misji przez ONZ ${ }^{31}$.

Ofensywa gospodarcza Chin powoduje niepokój wśród polityków i inwestorów zachodnich, ale pozornie taka sytuacja w dalszej perspektywie może zaowocować korzyściami i spowoduje zwiększenie inwestycji firm zachodnich. Bezpośrednim następstwem szczytu w 2006 roku było ustanowienie przy znacznym wsparciu finansowym banków chińskich, również państwowych ChinaAfrica Development Fund. Wartość tego funduszu oszacowano na 5 mld USD ${ }^{32}$. Dość powiedzieć, iż na realizację projektu gospodarczego MEFTA administracja prezydenta Busha przeznaczyła „tylko" 1 mld USD w latach 2003-2013. Ze względu na trudną sytuację gospodarczą w USA suma ta została drastycznie zredukowana przez prezydenta Baracka Obamę. Efekty ofensywy gospodarczej Pekinu w Afryce można dostrzec bardzo szybko. Wymiana handlowa pomiędzy Chinami a krajami afrykańskimi in extenso wzrosła z 2 mld USD w 1999 roku do 39,7 mld USD w 2006 roku. Od 2007 roku banki chińskie udzieliły pożyczek Afrykańczykom na kwotę 5 mld USD ${ }^{33}$. Chiny stały się w krótkim czasie, drugim po USA, partnerem handlowym Afryki i wyprzedziły np. Unię Europejską. Aktywna postawa inwestycyjna Chin powinna skłonić USA do podobnych działań, jednak $\mathrm{z}$ wielu powodów Amerykanie przegrywają konkurencję z Chińczykami. Główną przyczyną niepowodzenia Waszyngtonu jest postrzeganie Afryki jako terenu przede wszystkim niezbędnego do skutecznej walki $\mathrm{z}$ terroryzmem islamskim.

31 T. Graham Jr., Unending Crisis. National Security Policy after 9/11, Seattle 2012, s. 192.

32 US Strategy in Africa..., op.cit., s. 166.

33 People's Daily (2007), China - Africa trade hits US\$55.5 billion, http://english.peopledaily.com. cn/200701/30/eng20070130_346085.html, odczyt z dn. 25.01.2013. 
Inny, równie ważny powód stanowi zagadnienie praw człowieka w państwach rządzonych przez reżimy. Presja ze strony społeczeństwa amerykańskiego wymaga od rządu USA powiązania rozwiązań o charakterze ekonomicznym z procesami demokratyzacyjnymi i ochroną praw człowieka. Warto zauważyć, iż kolejne administracje USA, nie bacząc na nieprzestrzeganie praw człowieka, udzielały poparcia politycznego i wsparcia finansowego rządom autorytarnym w Maroku czy zwłaszcza w Egipcie na długo przed 2001 rokiem $^{34}$. Również reżim Kadafiego mógł liczyć na przychylność Amerykanów po 2003 roku, kiedy dyktator wziął na siebie pełną odpowiedzialność za atak terrorystyczny na Lockerby i zobowiązał się do wypłacenia odszkodowań rodzinom ofiar. Taka postawa wystarczyła, aby przekonać do swoich rządów Waszyngton i uzyskać rehabilitację wśród amerykańskich polityków. Już w 2006 roku USA zezwoliły Libijczykom na udział w programie International Military Education and Training (IMET), polegającym na szkoleniu oficerów afrykańskich w amerykańskich akademiach i instytucjach wojskowych. Ostatnie wydarzenia polityczne i ruchy demokratyczne w krajach Afryki Północnej obnażyły lata zaniedbań i nieprzygotowanie decydentów amerykańskich wobec zaistniałej nowej sytuacji. Dodatkowo wskazać należy na nieznajomość realiów społeczno-politycznych krajów tego regionu ze strony państw zachodnich. W sposób szczególny braki te zostały uwypuklone w przypadku Libii. Błędem okazała się polityka ustępstw i rehabilitacji międzynarodowej dyktatora Libii, prowadzona konsekwentnie od 2003 roku przez Unię Europejską oraz Stany Zjednoczone. Pułkownik Kadafi, do niedawna wiarygodny partner polityczno-biznesowy dla Zachodu (np. premiera Włoch), okazał się jednym z najbardziej zdeterminowanych i brutalnych arabskich dyktatorów $\mathrm{w}$ walce o pozostanie przy władzy w Libii ${ }^{35}$.

Pewien postęp w tej kwestii został poczyniony w 2003 roku. Spiritus movens aktywniejszej polityki USA wobec krajów regionu okazało się Bureau for Near East Affairs, wchodzące w skład Departamentu Stanu. Bezpośrednim skutkiem działań urzędników było wydanie w listopadzie 2003 roku decyzji o powstaniu The Greater Middle East Initiative (GMEI) ${ }^{36}$. Był to trzeci program ogłoszony

34 Strategy for Empire..., op.cit., s. 243.

35 T. Graham Jr., op.cit., s.193.

${ }^{36} \mathrm{Na}$ temat antecedencji powstania programu GMEI i stopnia jego implementacji trwają od lat dyskusje wśród analityków amerykańskich i dzielą to środowisko. Zwolennicy podkreślają polityczno-gospodarcze zalety tej inicjatywy, wskazując na GMEI jako przykład wykorzystania w polityce zagranicznej przez administrację Busha instrumentów innych niż kojarzona przez obserwatorów współczesnych stosunków międzynarodowych polityka hard power. Krytycy formułują kilka głów- 
po wydarzeniach z 11 września 2001 roku skierowany do krajów Afryki Północnej i Bliskiego Wschodu. W grudniu 2002 roku powołano do życia US Middle East Partnership Initiative, a kilka miesięcy później w lutym 2003 roku w Waszyngtonie prezydent Bush ogłosił decyzję o powstaniu US - Middle East Free Trade Area. Za formalny początek GMEI uznaje się przemówienie prezydenta G.W. Busha wygłoszone 6 listopada 2003 roku w American Enterprise Institute (AEI), w ramach którego działa National Endowment for Democracy (NED). Decyzją prezydenta Busha z budżetu NED wyasygnowano sumę $40 \mathrm{mln}$ USD na rzecz utworzenia nowej instytucji współpracy między USA a arabskimi krajami Afryki Północnej i Bliskiego Wschodu oraz Izraelem i Turcją ${ }^{37}$. Głównym celem inicjatywy prezydenta Busha było zinstytucjonalizowanie współpracy gospodarczej pomiędzy USA a krajami regionu. Integralną częścią programu, a nawet zdaniem Waszyngtonu warunkiem koniecznym było wyrażenie zgody tamtejszych władz na rozpoczęcie procesu demokratyzacji życia politycznego w ich krajach. Powodów ustanowienia tego forum współpracy było wiele, ale GMEI można również traktować jako próbę odpowiedzi na ofensywę chińską i alternatywę polityczno-gospodarczą, jaką daje na przyszłość regionowi ${ }^{38}$.

nych zarzutów. Wręcz oskarżają G.W. Busha, że pod pretekstem „demokratyzacji” państw Bliskiego Wschodu ukryty jest sprytny plan wykorzystania pod kątem gospodarczym przez amerykańskich przedsiębiorców związanych z nurtem neokonserwatystów. Z kolei poprzez ekspansję ekonomiczną neokonserwatyści dążą do kontrolowania geostrategicznych terenów roponośnych na Bliskim Wschodzie, a w konsekwencji do umocnienia USA na pozycji hegemona w globalnej gospodarce i polityce. Przeciwnicy podkreślają postawę ambiwalentną Waszyngtonu. Z jednej strony deklaruje chęć poszerzania obszarów na świecie objętych demokratycznymi formami rządów, przy równoczesnym wspieraniu rządów autorytarnych w tych krajach, w których dyktatorzy są eksponentem interesów amerykańskich, np. do 2010 r. prezydent Hosni Mubarak w Egipcie. Zob.: E.J. Girdner, Operation Iraqi Freedom: Invasion, Occupation and Consolidation of US Hegemony in Iraq, „Punjab Journal of Politics" 2004, nr 2 (28), s. 20-31.

37 E.J. Girdner, The Greater Middle East Initiative: Regime Change, Neoliberalism and US Global Hegemony, „Turkish Yearbook”, vol. XXXVI, s. 42, http://dergiler.ankara.edu.tr/dergiler/44/677/8621. pdf, odczyt z dn. 22.10.2012.

38 Pięć konkretnych obszarów współpracy w ramach GMEI zdefiniowano w sposób następujący: 1. GMEI jako forum omawiania i przygotowywania do wprowadzenia w życie niezbędnych reform, zachęcanie uczestników do zintensyfikowania współpracy politycznej i gospodarczej pomiędzy nimi, 2. utworzenie Greater Middle East Democracy Assistance Group, koordynowanej przez Amerykanów i Europejczyków w celu promocji politycznych rozwiązań demokratycznych wśród społczeństw państw członkowskich, 3. stworzenie w przyszłości międzynarodowej fundacji, której celem będzie monitorowanie przemian politycznych w państwach regionu, 4. powołanie do życia Greater Middle East Literacy Corps, 5. Utworzenie przez państwa G8 mechanizmu finansowego, którego zadaniem będzie wspieranie małych i średnich przedsiąbiorstw w krajach członkowskich GMEI, co w konsekwencji umożliwi wykrystalizowanie się arabskiej klasy średniej (Arab middle class). Stabilna i za- 
W 2004 roku, na początku istnienia programu, powołano do życia Greater Middle East Development Bank (GMED Bank), jako instrument liberalizacji stosunków gospodarczych i likwidacji barier pomiędzy państwami GMEI. Fakt utworzenia powyższej instytucji świadczy, iż rozwój ekonomiczny państw arabskich jest traktowany priorytetowo przez Stany Zjednoczone. Dzięki determinacji prezydenta Busha GMEI rozpoczęła rzeczywistą działalność już w 2004 roku³. Szczególną rolę do odegrania w ramach GMEI Waszyngton zarezerwował dla Turcji i tradycyjnego sojusznika w regionie - Izraela. Warto podkreślić, iż w tamtym okresie Izrael był jedynym demokratycznym państwem regionu. Ze względu na ten fakt Waszyngton wyznaczał mu szczególną rolę do odegrania w amerykańskim programie. W celu uniknięcia niepotrzebnych napięć pomiędzy Tel Avivem a państwami arabskimi, w ramach GMEI i zwiększenia szans na powodzenie inicjatywy, Amerykanie zrezygnowali z włączenia do jej prac problemu konfliktu palestyńsko-izraelskiego i sposobów jego rozwiązania. Zasadność intensyfikacji działań Waszyngtonu względem regionu potwierdzały dwa znamienne fakty: badania ONZ przeprowadzone w latach 2002-2003, a opublikowane w UN Arab Human Development Report (AHDP), oraz aktywność instytucjonalna NATO i Unii Europejskiej skierowana do Izraela, krajów arabskich oraz Turcji ${ }^{40}$.

Polityczny i gospodarczy obraz regionu, jaki wyłaniał się z raportu ONZ, nie napawał optymizmem. Za trzy najważniejsze problemy - bariery w rozwoju demokracji i wzroście gospodarczym krajów arabskich regionu - uznano: brak wolności, brak wykształcenia i wiedzy oraz eufemistycznie rzecz ujmując dyskryminację kobiet. Ponad $40 \%$ dorosłych Arabów, w tym $2 / 3$ to kobiety, to analfabeci, zaledwie $2 \%$ miało dostęp do Internetu, a jedynie 3,5\% miejsc w tamtejszych parlamentach zajmowały kobiety (nawet w krajach Afryki Subsaharyjskiej odsetek kobiet w parlamentach wynosił 8,4\%). Zdaniem ONZ kraje arabskie rejonu Afryki Północnej i Bliskiego Wschodu prezentowały najniższy stopień wolności obywatelskich. Powyższe problemy powodują niepokojące konsekwencje i tworzą realne zagrożenia dla bezpieczeństwa międzynarodowego. Wielu członków społeczeństw arabskich jest podatnych na propagandę grup fundamentalistów oraz działań terrorystów. Równie niepokojący jest wzrost liczby nielegalnych

sobna klasa średnia spowoduje, że poziom życia ulegnie poprawie i w ten sposób zostaną osłabione wpływy radykałów islamskich wśród Arabów. D. Neep, Dilemmas of Democratization in the Middle East; The „Forward Strategy of Freedom”, „Middle East Policy Council Journal” 2004, vol. 11, nr 3, s. 62.

39 A. Moens, op.cit., s. 173.

40 E.J. Girdner, The Greater Middle East Initiative..., op.cit., s. 45. 
imigrantów, najczęściej ludzi młodych, którzy w poszukiwaniu lepszych perspektyw życiowych podejmują ryzyko i decydują się na wyjazd do Europy lub USA. Według danych z raportu aż 51\% młodych Arabów zadeklarowało wolę wyjazdu. Z punku widzenia tamtejszych społeczeństw najważniejszy problem, poza brakiem wolności i niskim stopniem wykształcenia, stanowi bardzo trudna sytuacja gospodarcza krajów regionu. Przykładowo produkt krajowy brutto 22 krajów arabskich Afryki Północnej i Bliskiego Wschodu w 2002 roku wynosił mniej niż PKB Hiszpanii. Z drugiej strony 85000 członków rodzin w Arabii Saudyjskiej dysponuje majątkiem wartym 700 mld USD ${ }^{41}$.

Wbrew krytykom inicjatywa Amerykanów bardzo szybko, bo już w 2005 roku, przyniosła oczekiwane efekty. Prezydent Hosni Mubarak, dyktator Egiptu, zezwolił na powstanie Narodowego Zgromadzenia ds. Praw Człowieka. W Libii pułkownik Muommar Kadafi podjął decyzję o liberalizacji prawa; zniesiono specjalne ustawy, które wykorzystywano do walki politycznej. Z kolei władze Autonomii Palestyńskiej zobowiązały się do przeprowadzenia wolnych wyborów parlamentarnych. Król Arabii Saudyjskiej zaproponował powołanie Forum Narodowego Dialogu, w ramach którego mają zostać przygotowane wybory do rad miejskich. Jednak część rządów państw arabskich pozostała tradycyjnie nieufna wobec inicjatywy USA, a w niektórych społeczeństwach po raz kolejny przybrały na sile nastroje antyamerykańskie ${ }^{42}$. Sceptycznie do GMEI odnosiły się władze Syrii, Tunezji oraz Bahrajnu, oskarżając USA, iż pod pretekstem rozszerzania demokracji realizują swoje imperialne i neokolonialne interesy polityczne i prowadzą ekspansję gospodarczą korzystną przede wszystkim dla przedsię-

41 G.C. Gambill, Jumpstarting Arab Reform: The Bush Administration's Greater Middle East Initiative, „Middle East Intelligence Bulletin” 2004, vol. 6, nr 6-7, s. 32.

42 W 2005 roku agenda National Endowment for Democracy przeprowadziła w sześciu państwach arabskich badania opinii społecznej na temat oceny polityki zagranicznej USA wobec krajów Afryki Północnej i Bliskiego Wschodu. Aż 69\% pytanych stwierdziło, że w działaniach Waszyngtonu nie chodzi o wspieranie działań demokratycznych w regionie, ale o partykularne interesy polityczne i gospodarcze. Znamienne, iż najbardziej krytyczni okazali się Egipcjanie (78\%) oraz Marokańczycy (77\%), a więc narody, których rządy prowadziły lojalną politykę wobec USA. Egipt pod rządami Mubaraka był wręcz eksponentem interesów amerykańskich w tym ważnym rejonie świata. Tylko 6\% uznało, że zmiany demokratyczne w ich państwach mogą spowodować pozytywne efekty i wpłynąć realnie na poprawę warunków życia. 16\% uznało demokrację za bardzo ważną wartość, jednak amerykański sposób jej wprowadzania oceniono negatywnie. Middle East Not Swayed by Bush's Democracy Pledge, angus-reid.com, [za:] E.J. Girdner, The Greater Middle East Initiative..., op.cit., s. 70, http://dergiler.ankara.edu.tr/dergiler/44/677/8621.pdf, odczyt z dn. 26.10.2012. 
biorstw amerykańskich. Dla dyktatorów tych państw koronnym przykładem amerykańskiej „demokracji na bagnetach” była obecność wojsk amerykańskich w Iraku. Pomimo głosów krytycznych 22 maja 2004 roku 22 państwa Ligi Arabskiej podpisały Deklarację z Tunisu, w której zobowiązano się do wprowadzenia reform politycznych i liberalizacji stosunków gospodarczych. Dokument spotkał się z zadowoleniem ze strony Waszyngtonu ${ }^{43}$.

Dramatyczne wydarzenia z 11 września 2001 roku stały się cezurą czasową, która spowodowała przeformatowanie polityki zagranicznej Stanów Zjednoczonych. Ewolucja amerykańskiej polityki dotyczyła również krajów Afryki Północnej. Nowe wyzwania, przed którymi stanął współczesny świat cywilizacji zachodniej, zmieniły postrzeganie tego regionu przez administrację prezydenta George’a W. Busha. Od 2001 roku nastąpił wzrost znaczenia państw Maghrebu z punktu widzenia interesów politycznych Waszyngtonu. Wzrost zainteresowania ze strony USA obszarem Afryki Północnej spowodowany był następującymi czynnikami: walką z międzynarodowym terroryzmem, promocją praw człowieka oraz działaniami o charakterze gospodarczym. Jednak defensywne działania prezydenta Baracka Obamy na arenie międzynarodowej mogą spowodować powrót krajów Afryki Północnej do statusu regionu o niskim stopniu zainteresowania z punktu widzenia Stanów Zjednoczonych. Wycofanie wojsk amerykańskich z Iraku, rozpoczęcie zakończenia misji wojskowej w Afganistanie, a w związku z tym zakończenie w nieodległej przyszłości operacji Active Endeavour powodują, iż administracja prezydenta Obamy wysyła jednoznaczne sygnały o defensywnej polityce wobec krajów Afryki Północnej ${ }^{44}$. Dodatkowo brak skoordynowanych działań o charakterze polityczno-gospodarczym wobec krajów Maghrebu może w przyszłości spowodować marginalizację regionu w amerykańskiej polityce zagranicznej, a próżnię polityczną po USA mogą wypełnić nieobliczalne Chiny czy ekspansjonistyczna Rosja. Konsekwencją o szczególnym znaczeniu dla środowiska międzynarodowego, która może wynikać z braku przedstawienia

${ }^{43}$ Konsekwencją zadeklarowanej demokratyzacji przez 22 państwa arabskie było ogłoszenie na szczycie państw G8 kolejnego programu modernizacyjnego Broader Middle East and North African Initiative (BMENAI). Negocjacje i rozbieżności dotyczące warunków uczestnictwa w partnerstwie spowodowały, że końcowy dokument BMENAI pomiędzy państwami G8 a krajami arabskimi został podpisany jedynie przez przedstawicieli Afganistanu, Algierii, Bahrajnu, Jordanii, Tunezji, Turcji, Jemenu oraz Iraku. Za: G.C. Gambill, Jumpstarting Arab Reform..., op.cit., s. 47.

${ }^{44}$ O prerekwizytach polityki zagranicznej Baracka Obamy zob. A National Security Strategy of the United States of America, Washington D.C. 2010. 
propozycji współpracy przez Zachód, jest zagrożenie rozwinięciem wpływów przez ekstremalne siły islamskie nad tym ważnym i newralgicznym regionem świata. Instrumentalne potraktowanie krajów Maghrebu w wojnie przeciwko terroryzmowi w przeszłości i brak planu współpracy w przyszłości rodzą takie niebezpieczeństwo ${ }^{45}$.

45 Przykładem takiej niekonsekwentnej polityki prowadzonej w ostatnich latach może być Turcja. Zmiana polityka zagranicznej tego kraju islamskiego o dużym potencjale pokazuje, iż brak konkretnych rozwiązań i propozycji współpracy ze strony Europy i USA spowodował zacieśnienie związków gospodarczych i militarnych ze światem arabskim, w tym z Iranem. Taka perspektywa rozwoju sytuacji w wyniku defensywnej polityki USA wydaje się obecnie bardzo realna i niebezpieczna ze względów bezpieczeństwa zarówno dla państw tego regionu, jak i Stanów Zjednoczonych. 